\title{
Hardware Design and Lung Sound Detection Simulation to Analyze Lung Abnormalities Based on Arduino Mega, NodeMCU ESP32 and Internet of Things
}

\author{
Amperawan Amperawan ${ }^{1, *}$, Destra Andika ${ }^{1}$, Dewi Permatasari ${ }^{1}$, Sabilal \\ Rasyad $^{1}$, Aldi Wijaya ${ }^{1}$, Muhammad Taufiqurahman Arrasyid ${ }^{1}$, Zainudin b Mat \\ Taib $^{2}$, Nuwairani Azurawati bt Siha ${ }^{2}$ \\ ${ }^{I}$ Department of Electronic Engineering, Politeknik Negeri Sriwijaya, JL.Srijaya Negara BukitBesar, \\ Palembang, 30139, Indonesia. \\ ${ }^{2}$ Department of Electrical Engineering, Politeknik Mukah Serawak, JL. Oya-Mukah KM 7, Mukah Serawak, \\ 9640, Malaysia \\ *Corresponding author: amperawan230567@ gmail.com
}

\begin{abstract}
Hardware Design and Simulation of Lung Sound Detector to Analyze Lung Abnormalities Based on Arduino Mega and NodeMCU ESP32 is a development of auscultation technique which is supported by signal display on oscilloscope, organic light-emitting diodes and computer on the lung sound detection circuit system connected to NodeMCU ESP32. The design and simulation consists of a stethoscope as an initial detection, then amplified with a mic-condenser pre-amp circuit connected a band pass filter, a buffer amplifier entering ADC 0 (GPIO36) processed by NodeMCU ESP32 and sending data in the form of free frequency via Arduino Mega and NodeMCU ESP32 as transmitters. and mobile phones as receivers of the frequency form display of lung sounds. Software for NodeMCU ESP32 communication with mobile phone using Blink software based on Internet of Things (IoT). In detecting the condition of the patient's lungs, it provides information that on the signal display on oscilloscopes, organic lightemitting diodes, computers and mobile phone, namely by displaying the sound of the lungs when exhaling and inhaling air from the test results can detect lung sounds which have a frequency limit of $20 \mathrm{~Hz}$. up to $1000 \mathrm{~Hz}$. to make it easier for doctors to analyze the patient's lung abnormalities from the observed frequency.
\end{abstract}

Keywords : band pass filter, paru-paru, NodeMCU ESP32, IoT

\section{INTRODUCTION}

The main function of the lungs is as a temporary storage and exchange of oxygen and carbon dioxide. This organ works every day, so if there is the slightest damage to any part it will affect the body's functional and will be fatal to the body [3]. Diseases of the lungs can affect the respiratory tract starting from the trachea (windpipe) then branching into bronchi, then getting smaller (alveoli) and towards the entire lung field [4]. Lung disease can impair our ability to breathe, thereby harming our general health in the short or long term. According to the American Lung Association, about 35 million Americans suffer from chronic lung disease that may be avoided. Asthma, bronchitis, lung cancer, and chronic obstructive pulmonary disease are all included in the category of lung disease (COPD). [7]

With the advancement of technology, particularly in the health industry, it will be easier for people to recognize a disturbance or anomaly in some body organs early (in this case the lungs). A stethoscope is one of the most important tools for diagnosing illnesses and anomalies in the lungs. A stethoscope is a device that listens to noises in the lungs and respiratory organs. 
This technique is also known as auscultation, however it has issues and disadvantages.

In this auscultation technique because this technique is a subjective process where the results depend on a person's hearing ability, experience and ability to recognize differences between sounds [9].

To reduce the risk from the limitations of this auscultation technique, a design and simulation of a detecting system that can convert the sound signal produced by the lungs into a digital signal display makes it easier to recognize sound patterns produced by the lungs can determine the condition of the lungs

\section{LITERATURE REFERENCE}

In performing Hardware Design and Lung Sound Detection Simulation to Analyze Lung Abnormalities Based on Arduino Mega, NodeMCU ESP32 and Internet of Things need reference.

\subsection{NodeMCU ESP32}

Espressif Systems, the makers of the ESP8266 SoC, have released the ESP32, a low-cost System on Chip (SoC) Microcontroller. Tensilica's 32-bit Xtensa LX6 Microprocessor with integrated $\mathrm{Wi}-\mathrm{Fi}$ and Bluetooth is the successor to the ESP8266 SoC and is available in single-core and dual-core varieties.

The ESP32, like the ESP8266, has built-in RF components such as a Power Amplifier, a Low-Noise Receive Amplifier, an Antenna Switch, Filters, and an RF Balun. This makes creating hardware for ESP32 very simple because only a few external components are required.

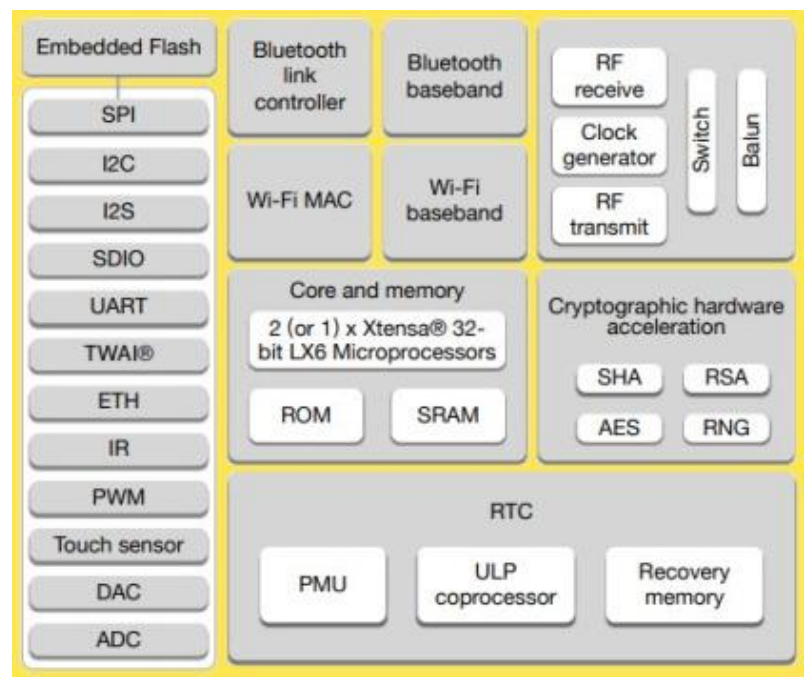

Figure 1 Designing hardware around ESP32

The system is implemented using Microcontroller ESP32, Arduino programming language and an
Android-based mobile application. The Microcontroller ESP32 is used to integrate all the electronic device in one environment. ESP32 is used because ESP32 has two cores, one core to run wifi functions and one core to execute uploaded programs. ESP32 also has a wifi and bluetooth module, and GPIO36 . ESP32 has a fairly large memory[2].

\subsection{Blynk Apps}

Blynk is an IoT platform that allows to control electronic equipment in real-time and remotely via an application on a smartphone. Blynk provides a dashboard that can be used by users to create a graphical interface based on widgets available in the Blynk application [4].

To start using Blynk, it is necessary to install the library on the Arduino IDE and create an account in the Blynk application. Once you have an account on it, you can create a Blynk interface by creating a new project. From the project, an authentication token will be sent to the email. This unique code will be used when programming Node MCU on the Arduino IDE.

Blynk is a new platform that lets users quickly create interfaces for controlling and monitoring hardware projects from their iOS or Android devices. Users can create a project dashboard after downloading the Blynk apps and arranging buttons, sliders, graphs, and other widgets on the screen. Users can utilize the widgets to turn pins on and off, as well as display data from sensors. Most Arduino boards, Raspberry Pi versions, the ESP8266, Particle Core, and a few other common microcontrollers and single-board computers are supported by Blynk, with more being added over time. It can control devices plugged into a computer's USB port as well as Wi-Fi and Ethernet shields from Arduino. [2]

\subsection{Pre-Amplifier Circuit}

Because the lung sounds are low in frequency, the pre-amplifier circuit assists to amplify the signal. The sound recorded by the mic-condenser stethoscope is then amplified by a pre-amplifier circuit, resulting in a high frequency lung sound signal. A schematic of the condenser mic pre-amp circuit is shown in Figure 2..[5].

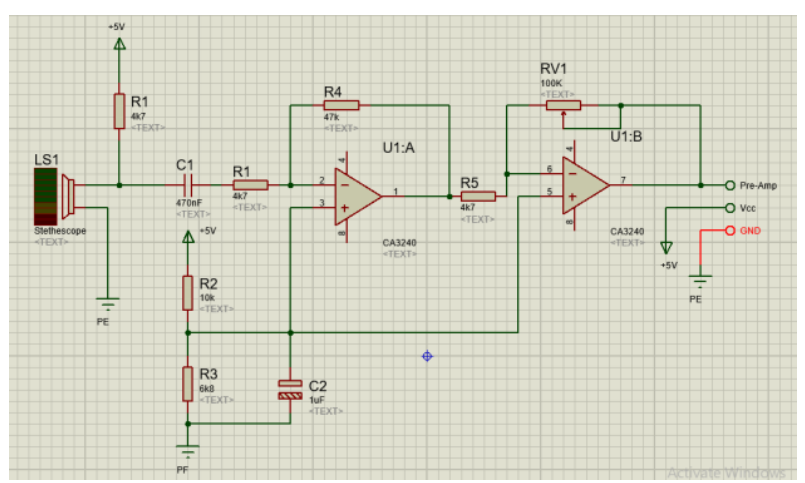

Figure 2 Prea-Amp 


\subsection{Band Pass Filter Circuit}

The band pass filter circuit used is used to pick up frequencies between $20 \mathrm{~Hz}$ to $1000 \mathrm{~Hz}$ in order to detect abnormalities of the lung signal in a person. Band Pass Filter is a type of filter that only passes signals over a certain time range and is considered to be signal in that frequency range. The Band Pass Filter has two dropout frequencies, namely the cut-off frequency down $(f L)$ and the upper cut off frequency $(f H)$. This second range of cut off frequencies is passed by the filter while the signal outside the frequency range will be muted. [11].

Bandpass filter serves to receive sensor data in a certain frequency band and reject all frequencies outside the frequency band. Bandpass filter that has a maximum output voltage (Vmax), or maximum voltage gain Ar. At a resonant frequency $\omega r$, if the frequency varies from resonance, the output voltage drops. There is a frequency above $\omega \mathrm{r}$ and one below $\omega \mathrm{r}$ where the amplification voltage is $0.707 \operatorname{Ar}$ [10].

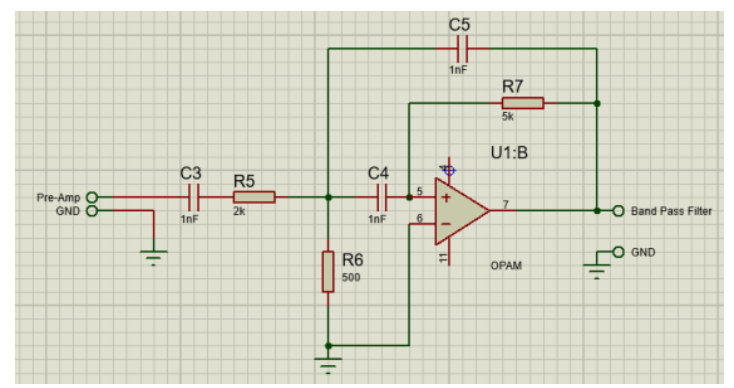

Figure 3 Band Pass Filter

This frequency is marked with $\mathrm{h}$ (top cutoff frequency) 1 (bottom cutoff frequency). The frequency band between $\mathrm{h}$ and $\mathrm{l}$ is the bandwidth [1].

$\mathrm{B}=\omega_{h}-\omega_{l}$

Narrow band and broad band bandpass filters are the two types of bandpass filters. If the bandwidth of the bandpass filter is less than one tenth of its resonant frequency (B 0.1r), the filter is narrow, and vice versa if the bandwidth is more than one tenth of its resonant frequency $(\mathrm{B}>0.1 \mathrm{r})$. The quality factor is the ratio of the resonant frequency to the bandwidth $(\mathrm{Q})[1]$.

$\mathrm{Q}=\frac{\omega r}{\mathrm{~B}}$

$\mathrm{R} 7=\frac{2}{\mathrm{BC}}$

$\mathrm{R} 5=\frac{R 7}{2 \mathrm{Ar}}$

$\mathrm{R} 5=\frac{R 7}{4 \mathrm{Q} 2-2 A r}$

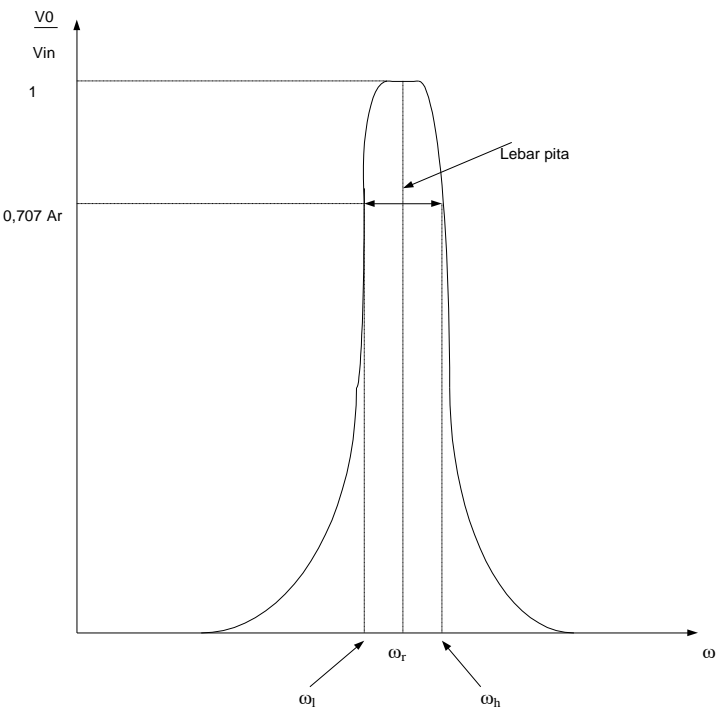

Figure 4 Frequency of a Bandpass Filter

\subsection{Buffer}

The buffer circuit's function is to produce an output signal that is identical to the input signal, despite the fact that the input resistance is high and the output resistance is low. The buffer design has a 1 time gain. [8].

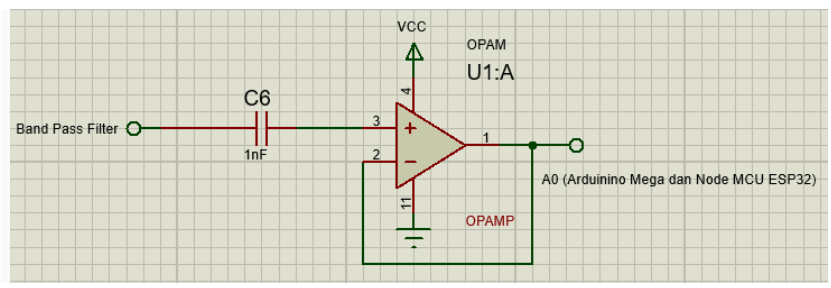

Figure 5 Buffer

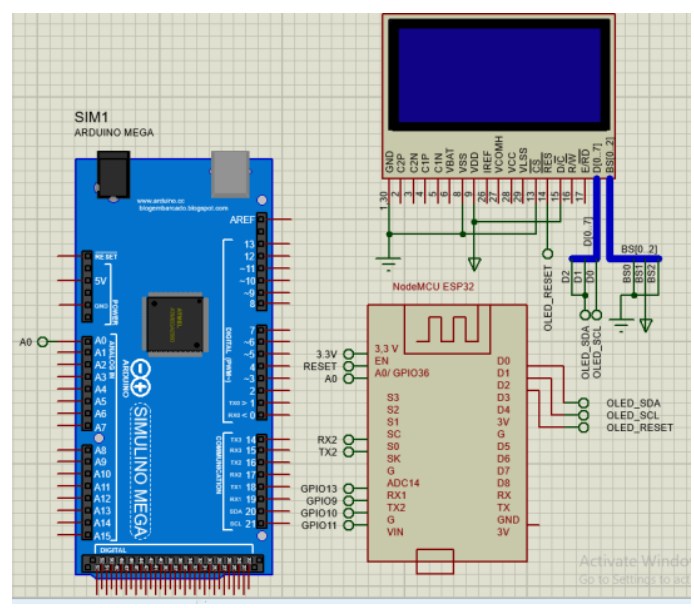

Figure 6 NodeMCU ESP 32 and Arduino Mega with A0 (ADC0) 


\section{EXPERIMENT}

The design of the system made hardware and simulations such as the block diagram below:

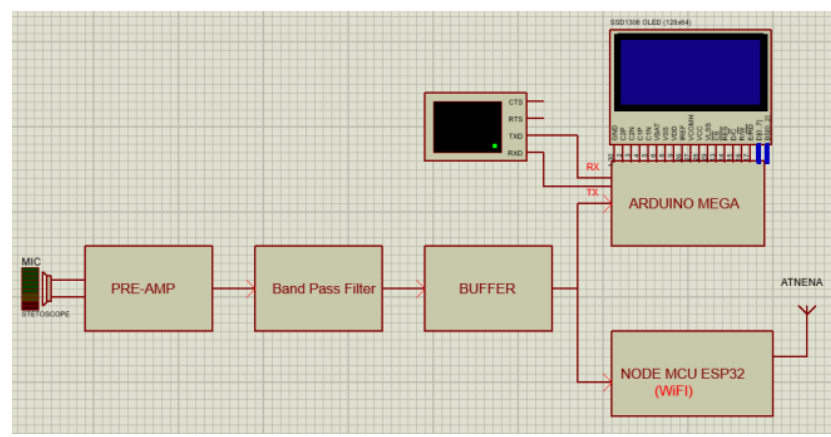

Figure 7 System Block Diagram

At the time of testing on the output of preamplifier then the measured frequency is in table 1.

Table 1 Pre-Amplifier Band pass filter, Buffer frequency output measurement

\begin{tabular}{|c|c|c|c|}
\hline Testing & $\begin{array}{l}\text { Read Pre- } \\
\text { Amplifier }\end{array}$ & $\begin{array}{l}\text { Read band } \\
\text { pass filter }\end{array}$ & Buffer \\
\hline 1 & $325 \mathrm{~Hz}$ & $322 \mathrm{~Hz}$ & $322 \mathrm{~Hz}$ \\
\hline 2 & $102 \mathrm{~Hz}$ & $102 \mathrm{~Hz}$ & $105 \mathrm{~Hz}$ \\
\hline 3 & $301 \mathrm{~Hz}$ & $301 \mathrm{~Hz}$ & $301 \mathrm{~Hz}$ \\
\hline 4 & $32 \mathrm{~Hz}$ & $32 \mathrm{~Hz}$ & $40 \mathrm{~Hz}$ \\
\hline 5 & $560 \mathrm{~Hz}$ & $560 \mathrm{~Hz}$ & $563 \mathrm{~Hz}$ \\
\hline 6 & $17 \mathrm{~Hz}$ & $0 \mathrm{~Hz}$ & $0 \mathrm{~Hz}$ \\
\hline 7 & $209 \mathrm{~Hz}$ & $209 \mathrm{~Hz}$ & $222 \mathrm{~Hz}$ \\
\hline 8 & $70 \mathrm{~Hz}$ & $70 \mathrm{~Hz}$ & $79 \mathrm{~Hz}$ \\
\hline 9 & $524 \mathrm{~Hz}$ & $550 \mathrm{~Hz}$ & $567 \mathrm{~Hz}$ \\
\hline 10 & $860 \mathrm{~Hz}$ & $865 \mathrm{~Hz}$ & $865 \mathrm{~Hz}$ \\
\hline
\end{tabular}

From the test results, measurements have been obtained that are almost read by the pre-ampilifier, band pass filter and buffer.

Table 2 Software Blink frequency output measurement.

\begin{tabular}{|c|c|}
\hline Testing & Read Software Blink \\
\hline 1 & $322 \mathrm{~Hz}$ \\
\hline 2 & $105 \mathrm{~Hz}$ \\
\hline 3 & $301 \mathrm{~Hz}$ \\
\hline 4 & $40 \mathrm{~Hz}$ \\
\hline 5 & $563 \mathrm{~Hz}$ \\
\hline 6 & $0 \mathrm{~Hz}$ \\
\hline 7 & $222 \mathrm{~Hz}$ \\
\hline 8 & $79 \mathrm{~Hz}$ \\
\hline 9 & $567 \mathrm{~Hz}$ \\
\hline 10 & $865 \mathrm{~Hz}$ \\
\hline
\end{tabular}

From the test results, measurements have been obtained that are almost read by software blink.

In this test using time/div $=1 \mathrm{~ms}$ and $1 \mathrm{volt} / \mathrm{div}$ to measure:
Measurements on the oscilloscope obtained from testing 1 frequency of $322 \mathrm{~Hz}$.

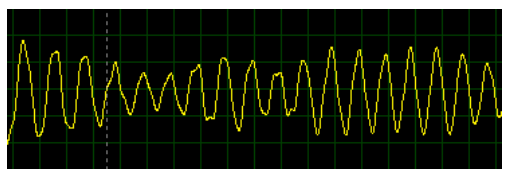

Figure 8 Lung Sounds at $322 \mathrm{~Hz}$

Measurements on the oscilloscope obtained from testing 2 frequency of $105 \mathrm{~Hz}$.

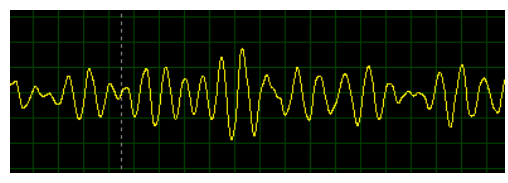

Figure 9 Lung Sounds at $105 \mathrm{~Hz}$

Measurements on the oscilloscope obtained from testing 3 frequency of $301 \mathrm{~Hz}$.

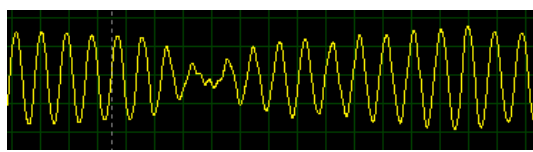

Figure 10 Lung Sounds at $301 \mathrm{~Hz}$

Measurements on the oscilloscope obtained from testing 9 frequency of $567 \mathrm{~Hz}$.

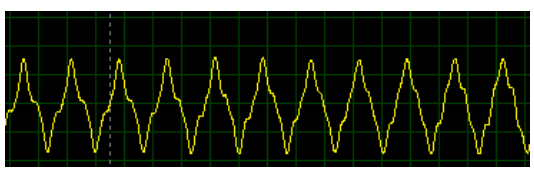

Figure 11 Lung Sounds at $567 \mathrm{~Hz}$

Measurements on the oscilloscope obtained from testing 10 frequency of $865 \mathrm{~Hz}$.

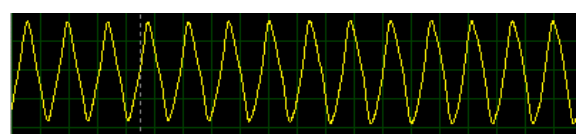

Figure 12 Lung Sounds at $865 \mathrm{~Hz}$

\section{RESULT AND DISCUSSION}

From the design of the bandpass filter, the results of the calculation of the resistance value are obtained.In this design, calculations are carried out by determining the value of the components $\mathrm{R} 5, \mathrm{R} 6, \mathrm{R} 7$, then the value of $\mathrm{Q}=0.25, \mathrm{Ar}=10, \omega \mathrm{r}=1 \mathrm{~K} \mathrm{rad} / \mathrm{s}$ and $\mathrm{C}=10 \mathrm{nf}$.

$$
\mathrm{B}=\frac{\omega r}{\mathrm{Q}}
$$




$$
\begin{aligned}
& \mathrm{B}=\frac{1 \times 10^{3}}{0,25} \mathrm{rad} / \mathrm{s} \\
& \mathrm{B}=4 \times 10^{3} \mathrm{rad} / \mathrm{s} \\
& \mathrm{R}_{7}=\frac{2}{\mathrm{BC}} \\
& \mathrm{R}_{7}=\frac{2}{(4 \mathrm{~K} \mathrm{rad} / \mathrm{s}) \times(10 \mathrm{nF})} \\
& \mathrm{R}_{7}=50 \mathrm{~K} \Omega
\end{aligned}
$$

The selected component R7 $=50 \mathrm{~K}$, because the time of testing this resistance value is more sensitive than the value of other components.

$$
\begin{aligned}
& \mathrm{B}=\frac{R 7}{2 \mathrm{Ar}} \\
& \mathrm{R}_{5}=\frac{50 \mathrm{~K} \Omega}{2 \times(10)} \\
& \mathrm{R}_{5}=2 \mathrm{~K} 5 \Omega .
\end{aligned}
$$

Selected component R5 $=2.5 \mathrm{~K} \Omega$

$$
\begin{aligned}
& \mathrm{R} 6=\frac{R 7}{4 \mathrm{Q} 2-2 \mathrm{Ar}} \\
& \mathrm{R}_{6}=\frac{50 \mathrm{~K} \Omega}{4(0,25)^{2}-2(10)} \\
& \mathrm{R}_{6}=500 \Omega
\end{aligned}
$$

Selected component R6 $=500 \Omega$

As for the buffer amplifier, the amplification is the same between the input and output of the amplifier buffer.

\section{CONCLUSION}

The conclusion is that the frequency from 0 to $1000 \mathrm{~Hz}$ is read by the pre-amplifier, band pass filter and buffer amplifier and the lung sound signal processing system by Arduino Mega and Node MCU ESP32 and data transmission via wifi has been read by mobile phone.
From the calculation results of the design of the band pass filter, the resistance value is $\mathrm{R} 5=2 \mathrm{~K} \Omega \mathrm{ohm}, \mathrm{R} 6=$ $500 \Omega$ and $\mathrm{R} 7=50 \mathrm{~K} \Omega$.

\section{ACKNOWLEDGMENTS}

It is hoped that the research can be continued into research with other funds, later it can be used by the general public.

\section{REFERENCES}

[1] Amperawan. (2006). Amssmec Robot Pencari Tujuan pada Labirin yang Tidak Terpetakan Menggunakan Transpoint Tesis Deparetmen Mikroelektronika ITB Indonesia, Bandung . Pp 2933.

[2] Andreasa, Door Security System for Home Monitoring Based on ESP32. 4th International Conference on Computer Science and Computational Intelligence 2019 (ICCSCI), 12-13 September 2019. Pp. 673-682 https: //www.sciencedirect.com/science/article/ pii/S1877050919311378

[3] A.R.A. Sovijarvi, J. Vanderschoot, J.E. Earis. (2000). Standarization of Computerezed Respiratory Sound Analysis. Europen Respiratory Review. ERS Journals Ltd 2000. pp. 856-857.

[4] Chico Hermanu, Hari M., Henry, P. S. Zainal A. Catur, H. (2022). Dual Mode System of Smart Home Based onInternet of Things. pp. 26-31.

DOI: 2715-5072 DOI: 10.18196/jrc.31147

[5] Dodik Kurniawan, Bingar Syaekti Eko Agus Supriyitno (1997). Rancang Bangun Alat Deteksi Suara Paru-Paru Untuk Menganalisa Kelainan Paru-Paru Berbasi Android. pp. 68-75. DOI: https://doi.org/10.21831/elinvo.v2i2

[6] Hans Paterkamp, Steve S. Kraman, \& Wodicka., G.R. (1997). Respiration sound advance beyond the stetoscope. America journal of respiratory and critical care medicine.

[7] Kahya, Y.P., Yerer, S., \& Cerid, O. (2001). A Wavelet-Based Instrument for Detection of Crackles in Pulmonary Sound. Paper presented at the engineering in Medicine and Biology Society, (2001). Proceeding of the 23rd Annual International Conference of the IEEE

[8] Coughlin, F. R., Driscoll, F.F., Operational Amplifiers and Linier Integrated Circuits, PranticeHall. 1982. Pp 60-62. 
[9] Simanjuntak, R. (2010). Sistem Instrumentasi untuk Identifikasi dan Analisis Suara Paru-Paru. Skripsi Deparetmen Fisika. Universitas Indonesia, Depok. Pp 18-19. http://lib.ui.ac.id

[10] Soemitro, W. H., Penguat Operasional dan Rangkaian Terpadu Linier. Penerbit Erlangga. 1992.
[11] Setiawan, A., Hariyadi, T., Mulyanti, B., Rancang Bangun Band Pass Filter Mikrostrip Hairpin Dengan Open Atub dan Detected Ground Sstructure.ELECTRANS,Vol.13, No.2, September 2014. 107-118. http: //jurnal.upi.edu/electrans 